\title{
Differences in metal sequestration between zebra mussels from clean and polluted field locations
}

\author{
Judith Voets ${ }^{\mathrm{a}}$, Erik Steen Redeker ${ }^{\mathrm{a}, \mathrm{b}}$, Ronny Blust ${ }^{\mathrm{a}}$, Lieven Bervoets ${ }^{\mathrm{a}, *}$ \\ a Laboratory for Ecophysiology, Biochemistry and Toxicology, Department of Biology, University of Antwerp, Groenenborgerlaan 171, 2020 Antwerp, Belgium \\ b Institute for Materials Research, Chemistry Division, Hasselt University, Agoralaan Building D G1-36, B 3590 Diepenbeek, Belgium
}

\section{A R T I C L E I N F O}

\section{Article history:}

Received 15 January 2009

Received in revised form 10 March 2009

Accepted 20 March 2009

\section{Keywords:}

Zebra mussel

Fractionation

Metallothionein

Cadmium

Copper

Zinc

\begin{abstract}
A B S T R A C T
Organisms are able to detoxify accumulated metals by, e.g. binding them to metallothionein (MT) and/or sequestering them in metal-rich granules (MRG). The different factors involved in determining the capacity or efficiency with which metals are detoxified are not yet known.

In this work we studied how the sub-cellular distribution pattern of cadmium, copper and zinc in whole tissue of zebra mussels from clean and polluted surface waters is influenced by the total accumulated metal concentration and by its physiological condition. Additionally we measured the metallothionein concentration in the mussel tissue. Metal concentration increased gradually in the metal-sensitive and detoxified sub-cellular fractions with increasing whole tissue concentrations. However, metal concentrations in the sensitive fractions did not increase to the same extent as metal concentrations in whole tissues. In more polluted mussels the contribution of MRG and MT became more important. Nevertheless, metal detoxification was not sufficient to prevent metal binding to heat-sensitive low molecular weight proteins (HDP fraction). Finally we found an indication that metal detoxification was influenced by the condition of the zebra mussels. MT content could be explained for up to $83 \%$ by variations in $\mathrm{Zn}$ concentration and physiological condition of the mussels.
\end{abstract}

(C) 2009 Elsevier B.V. All rights reserved.

\section{Introduction}

Accumulated metals in aquatic organisms can provide valuable information on metal bioavailability in the aquatic environment (Rainbow, 2002; Bervoets et al., 2005). However, total concentrations of accumulated metals in the tissues do not always give a reliable indication of metal toxicity (Cain et al., 2004; Vijver et al., 2004). Only that fraction of the metals that inappropriately interacts with physiologically sensitive target molecules (like small peptides, enzymes, DNA and RNA) or organelles (mitochondria, nuclei, membranes) is potentially toxic (Wallace et al., 2003; Wang and Rainbow, 2006; Wang and Wang, 2008). To regulate the internal availability of essential metals for metabolic functions and to avoid inappropriate binding of essential and non-essential metals to important bio-molecules, various sub-cellular systems have evolved. With this, essential metals in excess of metabolic requirements and non-essential metals are detoxified and/or excreted (Rainbow, 2002; Campbell et al., 2005, 2008). Excess of metals can

\footnotetext{
* Corresponding author at: Laboratory for Ecophysiology, Biochemistry and Toxicology, Department of Biology, University of Antwerp, Groenenborgerlaan 171, 2020 Antwerp, Belgium. Tel.: +32 326533 39; fax: +32 32653497

E-mail address: Lieven.bervoets@ua.ac.be (L. Bervoets).
}

be bound to the metal binding protein metallothionein (Vijver et al., 2004; Van Campenhout et al., 2008) and (subsequently) immobilized within granules (Marigómez et al., 2002). Metal-rich granules can be excreted via faeces or basal exocytosis towards haemocytes (Desouky, 2006). Nevertheless, for non-essential metals, often no or very slow elimination is observed (Roditi et al., 2000; do Amaral et al., 2005).

Techniques like differential centrifugation (Wallace et al., 2003), chromatographic separation (Van Campenhout et al., 2008), and microscopic analysis (Marigómez et al., 2002) give the opportunity to study the internal distribution of the metals. However, it is not yet fully understood whether and how factors such as total tissue concentration, uptake rate and physiological condition are involved in the capacity of metal detoxification.

Biological factors such as genetic background (Knapen et al., 2004), size (Wallace et al., 2003), physiological condition of the organism, or uptake route ( $\mathrm{Ng}$ et al., 2007) might be involved in the metal detoxification capacity. Metal detoxification and the maintenance of detoxification mechanisms might be energetically expensive. Therefore, the organisms in good condition might be able to invest more energy in metal detoxification. The energy status of an organism can give a good indication of its condition and can be determined by measuring energy stores (i.e. carbohydrates, proteins and lipids). Also condition-indices such as the tissue con- 
Table 1

Water characteristics and metal levels in water and sediment at the four locations.

\begin{tabular}{|c|c|c|c|c|c|c|c|c|c|c|}
\hline Locations & Cond. $(\mu \mathrm{s} / \mathrm{cm})$ & $\mathrm{pH}$ & $\mathrm{O}_{2}(\%)$ & $\mathrm{Ca}(\mathrm{mg} / \mathrm{l})$ & $C d(\mu g / 1)$ & $\mathrm{Cu}(\mu \mathrm{g} / \mathrm{l})$ & $\mathrm{Zn}(\mu \mathrm{g} / \mathrm{l})$ & Cd sed. $(\mu \mathrm{g} / \mathrm{g})$ & Cu sed. $(\mu \mathrm{g} / \mathrm{g})$ & Zn sed. $(\mu \mathrm{g} / \mathrm{g})$ \\
\hline Loc1 & 910 & 8.2 & 99.6 & 65.5 & $<0.05$ & 0.85 & 2.03 & 0.17 & 4.83 & 7.17 \\
\hline Loc2 & 554 & 8.1 & 110 & 62.9 & 0.23 & 0.57 & 0.25 & ND & ND & ND \\
\hline Loc3 & 532 & 7.8 & 93.5 & 52.7 & 1.20 & 8.26 & 63.4 & 2.46 & 57.3 & 438 \\
\hline Loc4 & 696 & 8.2 & 93.1 & 60.1 & 1.30 & 16.4 & 103.2 & 149 & 34.6 & 4410 \\
\hline
\end{tabular}

Cd sed.; Cu sed.; Zn sed.: metal levels in sediment expressed on a dry weight basis. ND: not determined

dition index (TCI) (weight normalized for size) and water content can give a valuable indication of the condition for several organisms (Smolders et al., 2004; Voets et al., 2006).

Mussels have been used extensively for monitoring water pollution. In the freshwater environment, zebra mussels have shown to be valuable monitoring organism. They are widespread, sedentary, easy to collect and handle and good accumulators. Furthermore, they might represent a significant entrance of metals in the ecological food chain and accumulate toxicants according to bioavailable levels in the environment (Hendriks et al., 1998; Kraak et al., 1991; Bervoets et al., 2005).

In this work we studied how zebra mussels under polluted conditions deal with an excess of accumulated $\mathrm{Cd}, \mathrm{Cu}$ and $\mathrm{Zn}$. To this, we studied how zebra mussels distribute excess of these accumulated metals sub-cellular and how this is influenced by the total metal concentration in the mussels. We also investigated whether the physiological condition of the mussels affects this sub-cellular distribution and/or if there is a relation between the physiological condition and the concentration of metals in the so-called metalsensitive fractions.

To achieve these goals, we determined the sub-cellular distribution of $\mathrm{Cd}, \mathrm{Cu}$ and $\mathrm{Zn}$ in whole tissue of zebra mussels from clean and polluted surface waters in Flanders, Belgium. We measured the metallothionein concentration. We defined the condition of the mussels by measuring the tissue condition index (TCI).

\section{Materials and methods}

\subsection{Sampling sites}

Mussels were sampled in September 2005 from two lakes (ponds) and two canals in Flanders (Belgium) with different levels of metal pollution. The selection of the locations was based on previous measurements of metal levels in zebra mussel tissue (Bervoets et al., 2005). Lake Walenhoek in Niel (further referred to as Loc1) was selected as a clean location. The lake Nekker in Mechelen (further referred to as Loc2) was slightly polluted, the Albert canal in Schoten (further referred to as Loc3) was considerably polluted and the canal of Beverlo in Lommel (further referred to as Loc4) was severely polluted with trace metals (Table 1 ).

The mussels were carefully removed from the substrate, selected by length (18-22 $\mathrm{mm}$ ) and transported to the laboratory in plastic barrels with water from the sampling site. Additionally $60 \mathrm{l}$ of water from each sampling site was collected, filtered $(0.45 \mu \mathrm{m})$ in the laboratory and stored at $4{ }^{\circ} \mathrm{C}$. This water was acclimated to $15^{\circ} \mathrm{C}$ just before use. In the laboratory, mussels were kept at $15^{\circ} \mathrm{C}$ in aerated and filtered site water to let them depurate. The water was renewed every $12 \mathrm{~h}$. After $60 \mathrm{~h}$, when the mussels produced no more faeces, they were dissected and stored at $-80^{\circ} \mathrm{C}$. For each location, 10 replicates each containing three mussels were used.

\subsection{Sub-cellular fractionation}

The mussel tissue was fractionated according to the protocol of Wallace et al. (2003) with minor modifications (Fig. 1) (Steen Redeker et al., 2007). Tissues were homogenized in six volumes of homogenization buffer $(20 \mathrm{mM}$ Tris- $\mathrm{HCl}, 5 \mathrm{mM} \beta$-mercapto ethanol, $0.1 \mathrm{mM}$ phenylmethanesulphonylfluoride (PMSF), $\mathrm{pH}$ 7.4). Tris-(hydroxylmethyl)-aminomethane (Tris), $\beta$-mercaptoethanol and PMSF were obtained from Sigma (Sigma-Aldrich, St Louis, MO). A sub-sample was taken from the homogenate for the determination of the total metal concentration and the metal concentration in all the separate fractions.

One $\mathrm{ml}$ of homogenate was centrifuged at $1450 \times \mathrm{g}$ (Eppendorf Centrifuge 5804R, Hamburg, Germany) for $15 \mathrm{~min}$. The supernatant was carefully removed for further fractionation. The pellet was re suspended in $200 \mu \mathrm{l}$ demineralized water and heated at $100^{\circ} \mathrm{C}$ for $2 \mathrm{~min}$. Five hundred microlitres of $1 \mathrm{M} \mathrm{NaOH}$ was added and the samples were incubated for $60 \mathrm{~min}$ at $65^{\circ} \mathrm{C}$. After incubation the samples were centrifuged at $10,000 \times g$ (Sorval Discovery ${ }^{\mathrm{TM}}$ 90 Ultra speed centrifuge, Newton, CT) for $30 \mathrm{~min}$ and the supernatant was transferred to another tube. The pellet was washed with $0.5 \mathrm{M} \mathrm{NaOH}$ and centrifuged again at $10,000 \times g$ for $30 \mathrm{~min}$. The supernatant was added to the previous supernatant fraction and contained the cellular debris (e.g. tissue fragments, membranes). The pellet contained the metal-rich granules (further called MRG) (Wallace et al., 2003).

The supernatant obtained by the first centrifugation step was ultra centrifuged at $100,000 \times \mathrm{g}$ for $90 \mathrm{~min}$. The resulting pellet contained organelles (nuclear, mitochondrial, microsomal fractions (further called organelles) (Wallace et al., 2003). The supernatant containing the cytosolic fraction was heated at $80^{\circ} \mathrm{C}$ for $10 \mathrm{~min}$ and subsequently cooled on ice for $60 \mathrm{~min}$. This fraction was centrifuged at $30,000 \times \mathrm{g}$ for $15 \mathrm{~min}$, which resulted in a supernatant fraction containing heat stable proteins (HSP), including metallothioneinlike proteins (MTLPs) and a pellet containing heat denaturated proteins (HDP). From the HSP fraction, a sub-sample was taken to determine MTLP levels. In summary, five fractions were retrieved, i.e. MRG, debris, organelles, HDP and HSP.

MRG and HSP, including MTs can be considered as biological detoxified metals (BDM), whereas organelles and HDP can be considered as the metal-sensitive fractions (MSF) (Wallace et al., 2003).

Various potential artefacts can complicate the interpretation of centrifugal fractionation results, such as breakage or clumping of particles, leakage of soluble constituents from organelles and overlap among sub-cellular fractions (Wallace et al., 2003).

\subsection{Metal analyses}

The different sub-samples were dried and digested in 5:1 ratio of $\mathrm{HNO}_{3} / \mathrm{H}_{2} \mathrm{O}_{2}$ in a microwave oven (Bervoets et al., 2005). Metal measurements $(\mathrm{Cd}-\mathrm{Cu}-\mathrm{Zn})$ were performed with ICP-MS (Varian Ultra Mass 700, Victoria, Australia). Analytical accuracy was determined using process blanks and certified reference material of the Community Bureau of Reference standard for trace elements in mussel tissue (CRM 278). Recoveries were within $10 \%$ of the certified values.

\subsection{Metallothionein quantification}

Total cytosolic MTLP concentrations were measured using the cadmium thiomolybdate saturation assay from Klein et al. (1994). Before use, the ion exchangers (CM-Sephadex, DEAE-Sephacel, 


\section{Zebra mussel homogenate}

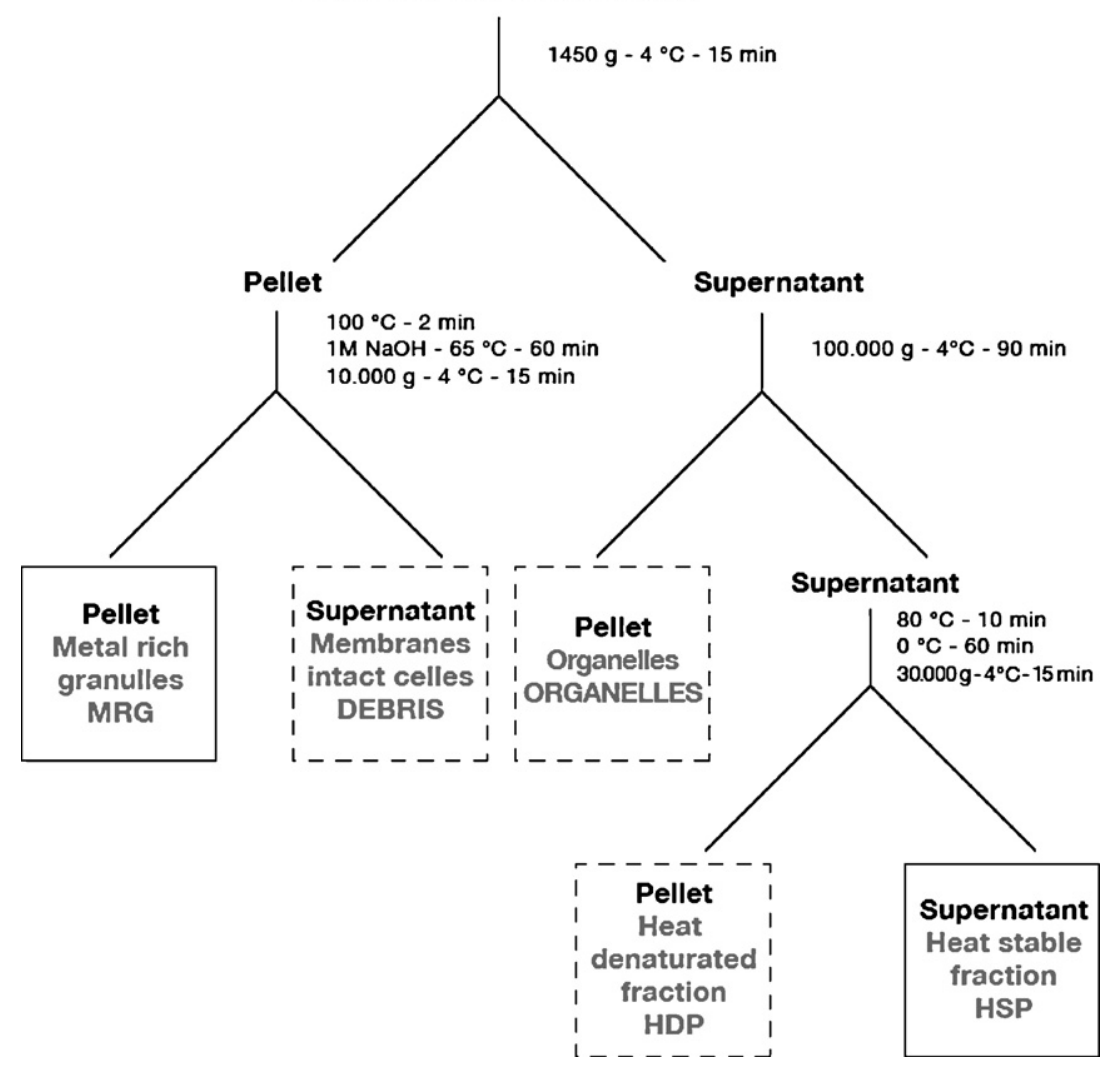

Fig. 1. Zebra mussel tissue was fractionated according to Wallace et al. (2003).

Chelex-100) were washed with 30 volumes of $10 \mathrm{mM}$ Tris-HCl, $1 \mathrm{M}$ $\mathrm{NaCl}, \mathrm{pH} 7.4$, and equilibrated with 30 volumes of $10 \mathrm{mM}$ Tris- $\mathrm{HCl}$, $85 \mathrm{mM} \mathrm{NaCl}, \mathrm{pH} 7.4$ (buffer A). Fifty micro litres of the cytosol was mixed with $10 \mu \mathrm{l}$ of $300 \mathrm{mM} \mathrm{ZnSO}_{4} \cdot 7 \mathrm{H}_{2} \mathrm{O}$ (Merck) in a $1.5 \mathrm{ml}$ vial and subsequently incubated with $10 \mu \mathrm{l}$ of $140 \mathrm{mM} \beta-\mathrm{ME}$ at room temperature for $30 \mathrm{~min}$. After incubation with $70 \mu \mathrm{l}$ acetonitrile (Merck) for $3 \mathrm{~min}, 500 \mu \mathrm{l}$ of buffer A and $100 \mu \mathrm{l}$ of CM-Sephadex $(66 \%, v / v$ suspension in buffer $A)$ were added. The mixture was shaken during $3 \mathrm{~min}$ and respectively incubated with $50 \mu \mathrm{l}$ bovine serum albumin ( $30 \mathrm{mg} / \mathrm{l}$, freshly prepared) and with $20 \mu \mathrm{l}$ of ammonium tetrathiomolybdate $(500 \mu \mathrm{M}$, freshly prepared in buffer A) both for $2 \mathrm{~min}$. After shaking with $100 \mu \mathrm{l}$ of DEAE-Sephacel (66\%, $\mathrm{v} / \mathrm{v}$ suspension in buffer $\mathrm{A}$ ) for $3 \mathrm{~min}$, the precipitate was removed by centrifugation at $8000 \times g$ for $5 \mathrm{~min}$. An aliquot of $600 \mu \mathrm{l}$ of the supernatant was saturated with $10 \mu \mathrm{l}$ of ${ }^{109} \mathrm{Cd}$-labeled $\mathrm{CdCl}_{2}$ ( $1 \mathrm{mM}, 740 \mathrm{kBq} / \mathrm{ml}$, specific activity) for $5 \mathrm{~min}$, thereby exchanging the endogenous $\mathrm{Cd}$ and $\mathrm{Zn}$. The excessive ${ }^{109} \mathrm{Cd}(\mathrm{II})$ was complexed and removed by Chelex-100. $\mathrm{CdCl}_{2}$ was supplied by Merck and ${ }^{109} \mathrm{Cd}(37 \mathrm{MBq} / \mu \mathrm{g} \mathrm{Cd})$ was obtained from Amersham Biosciences (Piscataway, NJ). Following a centrifugation step at $8000 \times g$ for $5 \mathrm{~min}, 500 \mu \mathrm{l}$ of the supernatant was incubated with $500 \mu \mathrm{l}$ of acetonitrile for $3 \mathrm{~min}$. The precipitate was removed by centrifugation and the ${ }^{109} \mathrm{Cd}(\mathrm{II})$ bound to MTLP was measured with a 'Wizard 3' 1480 Automatic gamma counter (PerkinElmer, Zaventem, Belgium). The MTLP concentrations were calculated on the basis of a molar ratio of Cd/MT of 7 (Kito et al., 1982).

\subsection{Tissue condition index}

The TCI is defined as the ratio between the dry weight of the tissue with the volume of the mussel. The calculation of the mussel volume $\left(\mathrm{Vol}_{\mathrm{m}}\right)$ was based on the length, width and height of the mussel with the formula (Voets et al., 2006)

Vol $_{\mathrm{m}}=\frac{\text { Length } \times \text { Width } \times \text { Height }}{2.77}$

\subsection{Statistics}

Analyses of variance (ANOVA, with post-hoc Duncan's multiple range test), Kruskal-Wallis test and correlation matrices were used to analyze the data, as appropriate. The data were tested for homogeneity of variance by the log-ANOVA test and for normality by the Kolmogorov-Smirnov test for goodness of fit. All tests were performed with STATISTICA 5.0 (StatSoft, Inc.). Differences were considered significant when $p$-values were $<0.05$. The statistical methods used are outlined in Sokal and Rohlf (1998).

\section{Results}

\subsection{Metal accumulation}

Metal concentrations in whole tissue of zebra mussels ranged from 0.69 to $40.6 \mathrm{nmol} / \mathrm{g}(\mathrm{w} / \mathrm{w})$ for Cd, from 16.9 to $79.0 \mathrm{nmol} / \mathrm{g}$ $(\mathrm{w} / \mathrm{w}$ ) for $\mathrm{Cu}$ and from 136.8 to $284.5 \mathrm{nmol} / \mathrm{g}(\mathrm{w} / \mathrm{w}$ ) for $\mathrm{Zn}$. Metal accumulation in zebra mussels $(\mathrm{Cd}, \mathrm{Cu}$ and $\mathrm{Zn})$ showed significant differences among the sampling sites (Fig. 2a-c). Cd, Cu and $\mathrm{Zn} \mathrm{lev-}$ els in the mussels were highest in mussels from Loc4, followed by mussels from Loc3 and Loc2.

\subsection{Sub-cellular metal compartmentalization}

The distribution of the metals over the different sub-cellular fractions, determined by differential centrifugation, showed clear differences between the metals. The relative distribution of the 

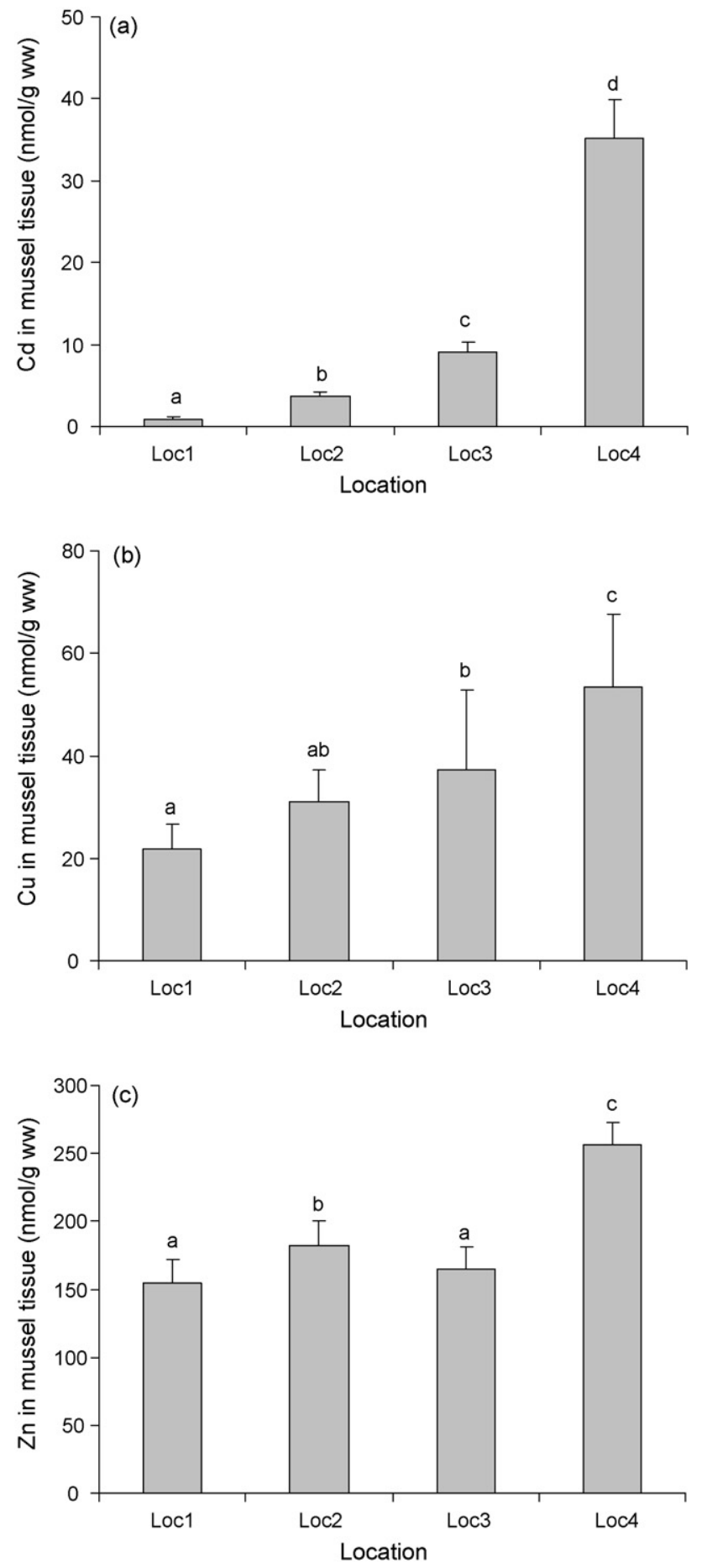

Fig. 2. Cadmium (a), copper (b) and zinc (c) concentrations in whole tissue of zebra mussels from field locations. Metals are expressed in nmol per $\mathrm{g}(\mathrm{w} / \mathrm{w})$. Mean values and standard deviation are given. Different letters represent significant differences between locations (ANOVA, $N=10, p<0.05$ ).

metals among the different fractions from the four locations is shown in Fig. 3. Cd was mainly present in the HSP fraction (60-70\% of total $\mathrm{Cd}$ ), $\mathrm{Cu}$ was mostly distributed in the fractions HSP, organelles and debris, while $\mathrm{Zn}$ was distributed over the fractions debris, organelles, HSP and HDP. For all metals, only a small amount was present in MRG (less than 10\%). The influence of environmental metal concentration on sub-cellular distribution was reflected in differences in metal distribution between mussels from clean and polluted locations (Fig. 3). At locations polluted with Cd (Loc4 and
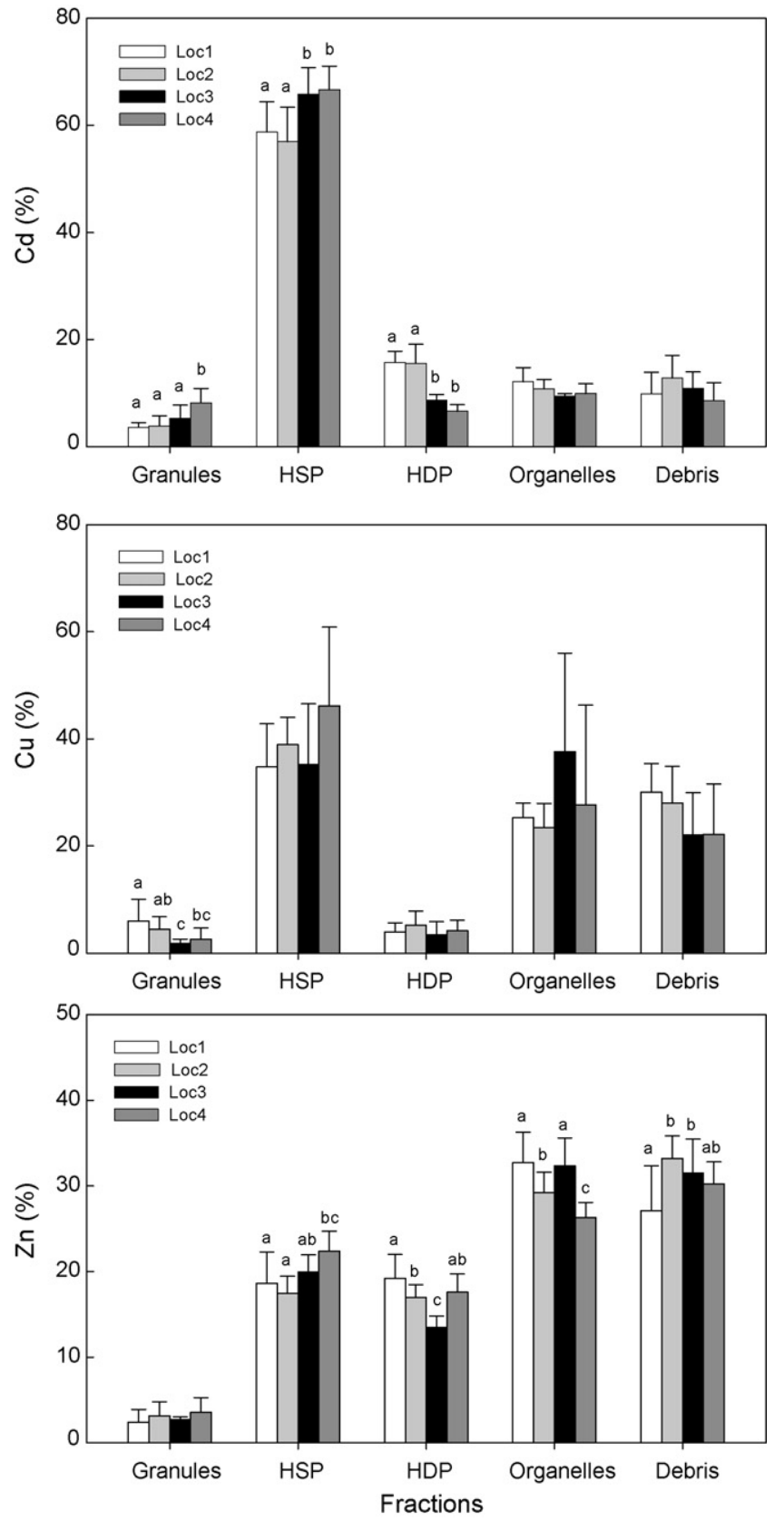

Figure 3. Distribution patterns (Mean \pm S.D.) of $\mathrm{Cd}(\mathrm{a}), \mathrm{Cu}$ (b) and $\mathrm{Zn}$ (c) over the sub-cellular fractions in percentage of whole tissue concentration in mussels from different field locations.

Loc3) a higher proportion of Cd was present in granules $(+4.4 \%)$ (not significant for Loc 3 ) and heat-stable proteins (+8.8\%), and relatively less $\mathrm{Cd}$ was bound to heat-sensitive proteins (HDP) $(-8.0 \%)$ compared to mussels from the clean locations (Loc1 and Loc2). Similar results were found for mussels from the $\mathrm{Zn}$ polluted location Loc4. Mussels from Loc4 had a higher proportion of $\mathrm{Zn}$ in the HSP fraction $(+4 \%)$ and a lower proportion of $\mathrm{Zn}$ in organelles $(-5.5 \%)$ than mussels from Loc1, Loc2 and Loc3. Mussels from Loc3, however, had a lower proportion of $\mathrm{Zn}$ bound to HDP, although they had no elevated whole tissue concentrations. For $\mathrm{Cu}$ on the other hand, we found almost no differences between mussels from the different locations. The within-site variation (between the replicates) in $\mathrm{Cu}$ concentrations in the sub-cellular fractions was higher in mussels from the polluted locations. 
Table 2

Correlation coefficients ( $r$-values) between metal concentrations in the sub-cellular fractions and whole tissue concentrations in zebra mussels $(N=40)$.

\begin{tabular}{llllll}
\hline & MRG & HSP & HDP & Organelles & Debris \\
\hline $\mathrm{Cd}$ & $0.92^{* * *}$ & $0.99^{* * *}$ & $0.96^{* * *}$ & $0.97^{* * *}$ & $0.88^{* * *}$ \\
$\mathrm{Zn}$ & $0.59^{* * *}$ & $0.89^{* * *}$ & $0.83^{* * *}$ & $0.83^{* * *}$ & $0.87^{* * *}$ \\
$\mathrm{Cu}$ & $-0.07^{\mathrm{NS}}$ & $0.74^{* * *}$ & $0.57^{* * *}$ & $0.84^{* * *}$ & $0.37^{*}$ \\
\hline
\end{tabular}

NS: non-significant.

${ }^{*} p<0.05$.

${ }^{* * *} p<0.001$.

Metal concentrations in all sub-cellular fractions (except for $\mathrm{Cu}$ in MRG) increased with increasing metal concentrations in whole mussel tissues. Correlations were highly significant for all metals and for almost all the fractions (Table 2). We calculated the amount of metals in the metal-sensitive fractions (organelles + HDP; potentially toxic) and in the detoxified fractions (HSP + MRG; presumed non-toxic) for all the mussels separately and plotted these values against the whole tissue concentration (Fig. $4 a-c$ ). For $\mathrm{Cd}$ and $\mathrm{Cu}$, most metals were present in the detoxified fractions, whereas for $\mathrm{Zn}$, most metals were present in the metal-sensitive fractions. From that figure it was clear that for $\mathrm{Cd}$ the relative importance of the so-called detoxified fraction increased with increasing total tissue level. For $\mathrm{Zn}$ the relative distribution remained almost unchanged with increasing whole tissue level. On the other hand, the excess of $\mathrm{Cu}$ in the mussels was mainly associated with organelles, relative importance of which increased with increasing whole body $\mathrm{Cu}$ concentration. This is an indication of an inefficient detoxification of $\mathrm{Cu}$ in zebra mussels.

\subsection{Metallothionein}

Metallothionein-like protein levels were measured in the HSP fraction of mussels from the different sampling sites (Fig. 5a). Background levels of MT, measured in the reference location Loc1 were $17.2 \pm 2.5 \mathrm{nmol} / \mathrm{g}(\mathrm{w} / \mathrm{w})$. Only in mussels from Loc4, levels were significantly elevated $(22.7 \pm 1.9 \mathrm{nmol} / \mathrm{g}, \mathrm{w} / \mathrm{w})$. Within each location, MTLP levels were significantly correlated to the $\mathrm{Zn}$ concentration in the HSP fraction (not for Loc4) and not to the $\mathrm{Cd}$ and $\mathrm{Cu}$ concentrations.

We calculated a theoretical amount of MT ( $\left.\mathrm{MT}_{\text {theor }}\right)$ necessary to bind all the $\mathrm{Cd}, \mathrm{Cu}$ and $\mathrm{Zn}$ in the HSP fractions, with the formula

$\mathrm{MT}_{\text {theor }}=\frac{[\mathrm{Cd}]}{7}+\frac{[\mathrm{Cu}]}{12}+\frac{[\mathrm{Zn}]}{7}$

whereby [Cd], [Cu] and $[\mathrm{Zn}]$ are the metal concentrations (in $\mathrm{nmol} / \mathrm{g}, \mathrm{w} / \mathrm{w}$ ) in the HSP fraction and the values 7, 12 and 7 are respectively the number of binding sites (metal-thiolate linkages) per MT molecule for $\mathrm{Cd}, \mathrm{Cu}$ and $\mathrm{Zn}$ respectively (Kägi and Schäffer, 1988). We calculated the ratio $\mathrm{MT} / \mathrm{MT}_{\text {theor }}$ for mussels from the different locations to compare the proportion of the MT binding sites that was bound to metals. In Loc1, levels of measured MTs were on average $3.6 \pm 0.4$ times higher than $\mathrm{MT}_{\text {theor }}$ which indicates that only $27 \%$ of the MT binding sites were occupied. This ratio decreased for mussels from more polluted locations (Fig. 5b).

\subsection{Tissue condition index}

As a measure of mussel condition we calculated the TCI. Mussels from the different locations showed significant differences in TCI (Fig. 6). Mussels from Loc2 had the best condition, followed by mussels from Loc1, Loc4 and Loc3. Within each location there was no significant correlation between the metal concentration in the metal-sensitive fractions (organelles and HDP) and the TCI. Also, when all pooled data were considered, TCI was not related to the $\mathrm{Cd}, \mathrm{Cu}$ and $\mathrm{Zn}$ concentrations in the metal-sensitive fraction or in the whole soft tissue.
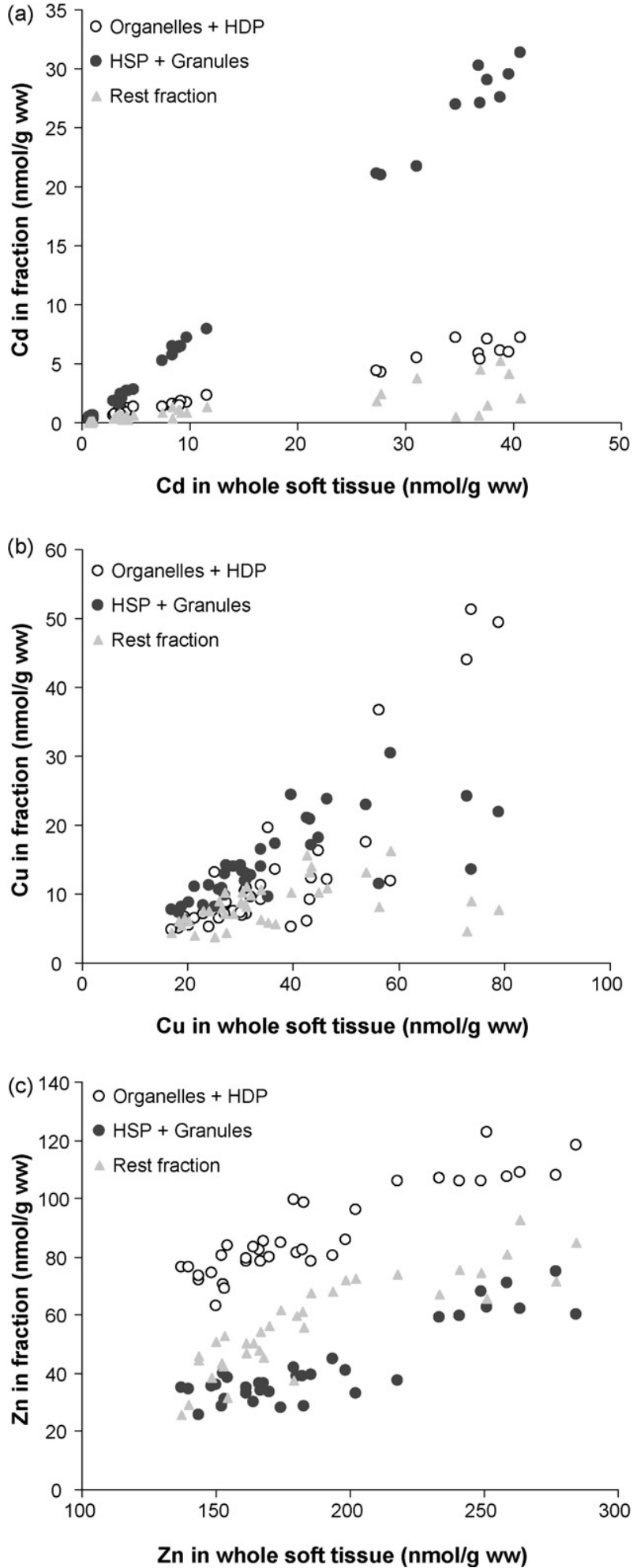

Figure 4. Distribution of $\mathrm{Cd}(\mathrm{a}), \mathrm{Cu}(\mathrm{b})$ and $\mathrm{Zn}$ (c) over the different sub-cellular fractions as a function of whole tissue metal concentration in Dreissena polymorpha. Data of all the locations are taken together $(N=40)$. For correlation coefficients see Table 2 .

To determine if the amount of MT is influenced by the condition of the mussels, we used a multiple regression model, whereby the metal concentrations in the HSP fraction and the TCI were used as independent variables to explain variation in MT concentrations. Zn and TCI were significant, both variables had a 

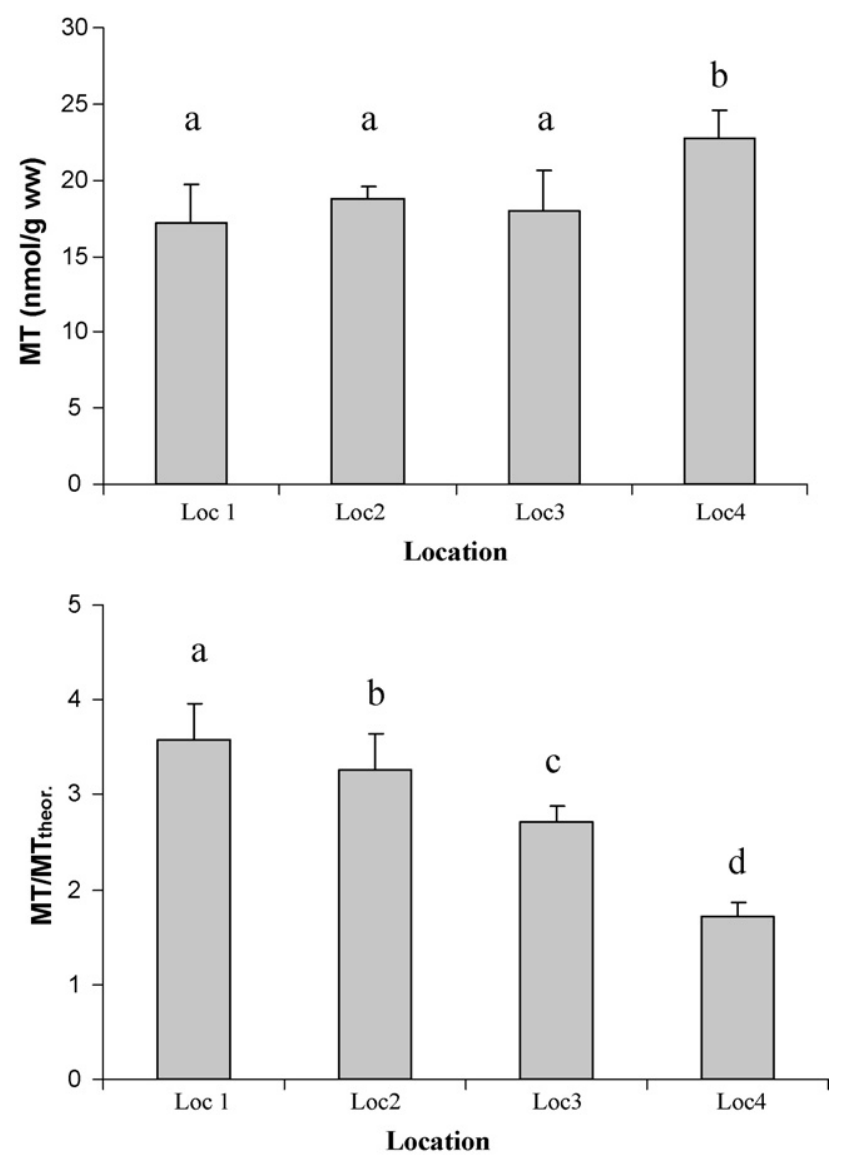

Figure 5. Metallothionein (MT) levels (a) MT levels in whole tissue of zebra mussels from field locations expressed in nmol per gram $(w / w)$. (b) The ratio of the measured MT concentration and the theoretical MT concentration necessary to bind all $\mathrm{Cd}, \mathrm{Cu}$ and $\mathrm{Zn}$ in the HSP fraction) in zebra mussels from four field locations. Mean values and standard deviation are given, $N=10$, bars with different letters are significant different (ANOVA, $N=10, p<0.001$ ).

positive relation and explained $83.4 \%$ of the variation in MT content (Table 3).

\section{Discussion}

Metal levels in the mussels ranged from low to very high concentrations depending on the exposure location. The lowest metal

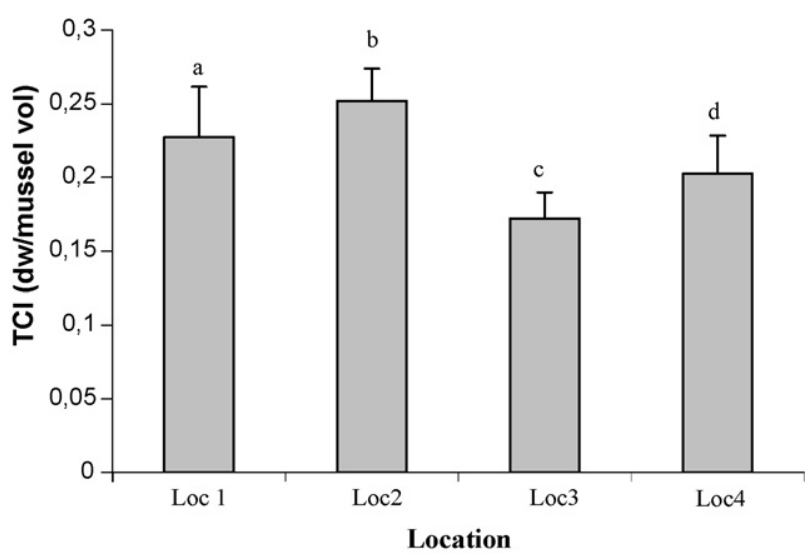

Figure 6. Tissue condition index (TCI; Mean \pm S.D., $N=10$ ) in whole tissue of zebra mussels from field locations. TCI is the ratio of the wet weight over mussel volume. Bars with different letters are significant different (ANOVA, $N=10, p<0.05$ ).
Table 3

Results of the multiple regression model, whereby variation in the MT level in zebra mussels is explained by the $\mathrm{Zn}$ concentration in the HSP fraction and the TCI of the mussels.

\begin{tabular}{lcc}
\hline Regression summary & $R^{2}=0.834$ & \\
\cline { 2 - 3 } & $a \pm$ S.E. & $p$ value \\
\hline Intercept & $6.46 \pm 1.51$ & $<0.001$ \\
Zn & $0.220 \pm 0.018$ & $<0.001$ \\
TCI & $20.98 \pm 5.64$ & $<0.001$ \\
\hline
\end{tabular}

levels, measured in mussels from Loc1, were comparable to levels measured in the Ysselmeer and Markermeer (NL) (Hendriks et al., 1998), which are considered as good reference locations. Mussels from Loc2 had slightly elevated Cd and Zn concentrations. Mussels from Loc3 had elevated $\mathrm{Cd}$ and $\mathrm{Cu}$ concentrations and mussels from Loc 4 were highly contaminated with $\mathrm{Cd}, \mathrm{Cu}$ and $\mathrm{Zn}$ compared to levels reported elsewhere in resident mussels (Bervoets et al. 2005; Hendriks et al., 1998).

The range of metal concentrations accumulated in the zebra mussels was much wider for the non-essential metal $\mathrm{Cd}$, than for the essential metals $\mathrm{Cu}$ and $\mathrm{Zn}$. This seems to confirm that zebra mussels have, like most aquatic organisms, mechanisms to regulate (at least to a certain extent) uptake and/or excretion of essential metals (Bervoets et al., 2004). For the non-essential element Cd, there appears to be no mechanism to regulate or limit uptake or excretion and therefore the importance of internal metal storage in detoxified forms increases. Indeed, as measured by centrifugal fractionation Cd was mainly bound to heat stable proteins (59-72\%). Nevertheless, Cd detoxification was not sufficient to prevent $\mathrm{Cd}$ from binding to metal-sensitive fractions. Even in mussels from Loc1, which contained Cd concentration close to reference values, Cd was also present in the metal-sensitive pool.

$\mathrm{Cu}$ was mostly bound to heat stable proteins or associated with organelles (differential centrifugation). The main part of $\mathrm{Cu}$ in the cytosol was bound to metallothionein, indicating that metallothioneins have an important role in $\mathrm{Cu}$ detoxification; however, also other heat stable proteins (e.g. heat shock proteins) may play a significant role in $\mathrm{Cu}$ detoxification or regulation (Clayton et al., 2000).

Zn was distributed more equally among the different fractions. Only $14-26 \%$ of the $\mathrm{Zn}$ was bound to metallothionein and other heat stable proteins. The main fraction of $\mathrm{Zn}$ was associated with organelles (23-36\%).

For $\mathrm{Cd}, \mathrm{Cu}$ and $\mathrm{Zn}$ we found a gradual increase of the metals in metal-sensitive fractions as whole tissue concentrations increase. Even at low tissue concentrations, we found a dose-dependent increase of $\mathrm{Cd}$ in the fractions HDP and HSP. For $\mathrm{Zn}$ and $\mathrm{Cu}$, correlations between metals in the sensitive fractions and the whole tissue concentration were not as strong as for Cd, which might imply regulation of these metals. However, for none of the metals, there was a sign of a threshold level below which excess of metals was successfully detoxified. Also in mussels from Loc4, with higher exposure concentrations no indications that detoxified fractions were saturated were found.

The critical body residue (CBR) is defined as the threshold concentration of a substance in an organism that marks the transition between no and adverse effects (McCarty and Mackay, 1993; Hickie et al., 1995). This concept suggests that as long as 'the exposure concentration' is below a certain threshold level, organisms are able to store the accumulated metals in detoxified forms. Above that threshold, organisms are no longer able to sequester additional metals in detoxified forms and as a consequence metals will interact with sensitive compartments and binding sites (Wang et al., 1999). For Cu we found some indication of a threshold level, but on a whole tissue concentration level. Within-site variation in 
$\mathrm{Cu}$ concentration in mussel tissue was high in the polluted locations Loc4 and Loc3. It appeared that mussels were able to regulate total body concentrations up to a certain level. When that level was exceeded, accumulation occurred at much higher level and most of these metals ended up in the organelles.

Similar results were observed in several indigenous organisms captured along a metal pollution gradient, e.g. in the freshwater fish, Perca flavescens (Giguère et al., 2006), in the freshwater bivalve, Pyganodon grandis (Campbell et al., 2005) and in aquatic insects (Cain et al., 2004). These organisms all showed a gradual increase of metal concentrations in various metal-sensitive and metal-detoxified sub-cellular fractions with increasing environmental metal levels. In these studies there was no evidence for a lower threshold exposure concentration below which the incoming metals are completely detoxified, neither an upper concentration threshold beyond which metal detoxification completely ceases to function. However, Campbell et al. (2005) found that Cd bound to the HDP fraction stayed relatively constant at low Cd concentrations in the gills of the freshwater mussel $P$. grandis, while metals in the MT pool increased with total gill concentration. Wang et al. (1999) found that Cd levels in the heat-sensitive low molecular weight pool stayed more or less constant below exposure concentrations of $1 \mathrm{nM} \mathrm{Cd}^{2+}$. Beyond this concentration, metal levels in this fraction increased rapidly. Despite this, Cd accumulation progressively increased in the MT fraction, with no sign of a threshold concentration.

The metal distribution pattern in indigenous organisms is often not consistent with distribution patterns observed in transplant experiments or in laboratory experiments. For Cd in Littorina littorea (Langston and Zhou, 1986) a higher proportion of the metals was present in detoxified form in indigenous than in laboratoryexposed organisms. Couillard et al. (1995) found clear differences in internal distribution of $\mathrm{Cd}$ in $P$. grandis, transplanted from a reference lake to a contaminated lake for 400 days compared to the indigenous mussels. In the indigenous mussels much more $\mathrm{Cd}$ was present in the MT fraction. In indigenous mussels under field conditions, it is not likely to find a threshold level above which metal detoxification mechanisms stop functioning since that would cause an uncontrolled accumulation of metabolically available metals in time, resulting in increased toxicity. This effect was observed in a study of Baudrimont et al. (1999) in the freshwater mussel Corbicula fluminea transplanted along a polymetallic contamination gradient. They observed a shut-down in MT synthesis, which was rapidly followed by the death of the transplanted molluscs.

Although in our study metal levels gradually increased in metal-sensitive fractions, the relative contribution of $\mathrm{Cd}$ and $\mathrm{Zn}$ in the metal-sensitive fractions (HDP for $\mathrm{Cd}$ and organelles for $\mathrm{Zn}$ ) decreased, while the relative contribution of $\mathrm{Cd}$ and $\mathrm{Zn}$ in detoxified fractions (MRG and HSP) increased with increasing whole tissue concentration. This was reflected in differences in metal distribution in mussels from the clean (Loc1) and polluted locations (Loc3 en Loc4). Mussels from Loc3 en Loc4 stored a higher proportion of $\mathrm{Cd}$ and $\mathrm{Zn}$ in non-toxic forms (HSP fraction and granules). For $\mathrm{Cu}$, we did not find this change in distribution pattern. In contrast, with increasing whole tissue concentration, more $\mathrm{Cu}$ was found in organelles. This decreased relative contribution of $\mathrm{Cd}$ and $\mathrm{Zn}$ in the HDP fraction, combined with an increased proportion of $\mathrm{Cd}$ in the HSP fraction was also observed in perch liver (P. flavescens) by Giguère et al. (2006).

Organisms seem to partially protect their metal-sensitive fractions (heat-sensitive proteins and organelles) from binding with $\mathrm{Cd}$ and $\mathrm{Zn}$ by increasing the proportion of metals in non-toxic forms. The extent to which organisms are able to protect themselves against metal toxicity seems species and tissue specific (Wang et al., 1999; Campbell et al., 2005; Giguère et al., 2006).
The internal distribution of metals follows an equilibriumdependent exchange of metals among cytosolic ligands, whereby, similar to the external environment, the stability constants of the metal-ligand complexes will determine the internal speciation. Trace metals like $\mathrm{Cd}, \mathrm{Cu}$ and $\mathrm{Zn}$ have a high affinity for sulphur and nitrogen containing functional groups (Nieboer and Richardson, 1980), but can bind to any molecule with an affinity for that metal. Many of the amino acids of which proteins are made of contain sulphur and/or nitrogen and therefore there is no shortage of potential binding sites for these metals within cells (Luoma and Rainbow, 2008). Therefore, it is likely that all metals that enter the cell as free ions will quickly be bound to bio-molecules. Metallothioneins have because of their high cysteine content a high affinity for metals like Cd, Cu and Zn (Coyle et al., 2002) and although metallothioneins in the cytosol were not saturated with $\mathrm{Cd}, \mathrm{Cu}$ and $\mathrm{Zn}$, it seems they can not fully prevent the inappropriate binding of metals to metal-sensitive fractions. In clean locations, less than one third of the metallothionein binding sites were occupied by $\mathrm{Cd}$, $\mathrm{Cu}$ and $\mathrm{Zn}$. Other metals like $\mathrm{Ag}$ and $\mathrm{Hg}$ also have a high affinity for metallothionein, but these metals were present in much lower concentration and therefore we assume that a high proportion of the metallothionein binding sites were still available. In the more polluted locations, MT binding sites were also not completely saturated, although a higher proportion of the binding sites were bound with $\mathrm{Cd}, \mathrm{Cu}$ and $\mathrm{Zn}$. Metallothionein levels increased with increasing metal levels in the mussels. The relation was strongest with the $\mathrm{Zn}$ concentration in the HSP fraction even at low metal concentrations, like in mussels from Loc1. An interesting question was proposed by Campbell et al. (2005): "Why don't bivalves synthesise enough MT to keep Cd (and other metals) off the metal-sensitive sites and avoid the associated toxic effects?" He speculates that under chronic conditions the animal establishes a trade-off between the "cost" of detoxifying the Cd and the "cost" of allowing some $\mathrm{Cd}$ to spill over onto the metal-sensitive sites. This reasoning can also be applied to other metals in excess of metabolic requirements. The maintenance of a tolerance mechanism may be energetically expensive (Postma et al., 1995) and this might imply that organisms in a better condition, e.g. due to high food abundance, have more energy available to invest in metal detoxification. In our study a relationship was found between the MT level and the condition of the zebra mussels. In a multiple regression model $83.4 \%$ of the variation in MT concentration was explained by the tissue condition index and the $\mathrm{Zn}$ concentration in the HSP fraction.

The tissue condition index was also related to the metal concentrations in the mussels. In Loc4, mussels had a better condition than Loc3, although metal concentrations in this location were much higher. Also when the TCI was related to the $\mathrm{Cd}, \mathrm{Cu}$ and $\mathrm{Zn}$ concentrations in the metal-sensitive fractions, no relation was found. Therefore, it seems that other factors than metal pollution might be more important in determining the condition of the mussels. Schneider (1992) developed a growth model for zebra mussels in the Great Lakes and found that the growth rate (increase in biomass) was mainly dependent on the temperature and food availability. In our study, the mussels were collected after the reproductive season and therefore it is possible that they were still recovering from their reproductive efforts. The rate at which mussels in the different locations recovered might be different because of differences in the food availability and temperature in the water.

\section{Acknowledgments}

This project was supported by the University of Antwerp via a Nieuw Onderzoeks Initiatief project of the Bijzonder Onderzoeks Fonds (BOF44704/UA). Furthermore, we would like to thank Lien Van Gool for the English revision. 


\section{References}

Baudrimont, M., Andres, S., Metivaud, J., Lapaquellerie, Y., Ribeyre, F., Maillet, N., Latouche, C., Boudou, A., 1999. Field transplantation of the freshwater bivalve Corbicula fluminea along a polymetallic contamination gradient (River Lot France). II. Metallothionein response to metal exposure. Environ. Toxicol. Chem. $18,2472-2477$

Bervoets, L., Voets, J., Chu, S.G., Covaci, A., Schepens, P., Blust, R., 2004. Comparison of accumulation of micropollutants between indigenous and transplanted zebra mussels (Dreissena polymorpha). Environ. Toxicol. Chem. 23, 1973-1983.

Bervoets, L., Voets, J., Covaci, A., Chu, S.G., Qadah, D., Smolders, R., Schepens, P., Blust, R., 2005. Use of transplanted zebra mussels (Dreissena polymorpha) to assess the bioavailability of microcontaminants in Flemish surface waters. Environ. Sci. Technol. 39, 1492-1505.

Cain, D.J., Luoma, S.N., Wallace, W.G., 2004. Linking metal bioaccumulation of aquatic insects to their distribution patterns in a mining-impacted river. Environ. Toxicol. Chem. 23, 1463-1473.

Campbell, P.G.C., Giguere, A., Bonneris, E., Hare, L., 2005. Cadmium-handling strategies in two chronically exposed indigenous freshwater organisms - the yellow perch (Perca flavescens) and the floater mollusc (Pyganodon grandis). Aquat. Toxicol. 72, 83-97.

Campbell, P.G.C., Kraemer, L.D., Giguere, A., Hare, L., Hontela, A., 2008. Subcellular distribution of cadmium and nickel in chronically exposed wild fish: inferences regarding metal detoxification strategies and implications for setting water quality guidelines for dissolved metals. Hum. Ecol. Risk Assess. 14, 290-316.

Clayton, M.E., Steinmann, R., Fent, K., 2000. Different expression patterns of heat shock proteins hsp 60 and hsp 70 in zebra mussels (Dreissena polymorpha) exposed to copper and tributyltin. Aquat. Toxicol. 47, 213-226.

Couillard, Y., Campbell, P.G.C., PellerinMassicotte, J., Auclair, J.C., 1995. Field transplantation of a freshwater bivalve Pyganodon grandis across a metal contamination gradient (River Lot, France): II. Metallothionein response to Cd and $\mathrm{Zn}$ exposure, evidence for cytotoxicity, and links to effects at higher level of biological organization. Can. J. Fish. Aquat. Sci. 52, 703-715.

Coyle, P., Philcox, J.C., Carey, L.C., Rofe, A.M., 2002. Metallothionein: the multipurpose protein. Cell. Mol. Life Sci. 59, 627-647.

Desouky, M.M.A., 2006. Tissue distribution and subcellular localization of trace metals in the pond snail Lymnaea stagnalis with special reference to the role of lysosomal granules in metal sequestration. Aquat. Toxicol. 77, 143-152.

do Amaral, M.C.R., Rebelo, M.D., Torres, J.P.M., Pfeiffer, W.C., 2005. Bioaccumulation and depuration of $\mathrm{Zn}$ and $\mathrm{Cd}$ in mangrove oysters (Crassostrea rhizophorae, Guilding, 1828) transplanted to and from a contaminated tropical coastal lagoon. Mar. Environ. Res. 59, 277-285

Giguère, A., Campbell, P.G.C., Hare, L., Couture, P., 2006. Sub-cellular partitioning of cadmium, copper, nickel and zinc in indigenous yellow perch (Perca flavescens) sampled along a pollymetallic gradient. Aquat. Toxicol. 77, 178-189.

Hendriks, A.J., Pieters, H., de Boer, J., 1998. Accumulation of metals, polycyclic (halogenated) aromatic hydrocarbons, and biocides in zebra mussel and eel from the Rhine and Meuse rivers. Environ. Toxicol. Chem. 17, 1885-1898.

Hickie, B.E., McCarty, L.S., Dixon, D.G., 1995. A residue-based toxicokinetic model for pulse-exposure toxicity in aquatic systems. Environ. Toxicol. Chem. 14, 2187-2197.

Kägi, J.H.R., Schäffer, A., 1988. Biochemistry of metallothionein. Biochemistry 27, 8509-8515.

Kito, H., Ose, Y., Mizuhira, V., Sato, T., Ishikawa, T., Tazawa, T., 1982. Separation and purification of $(\mathrm{Cd}, \mathrm{Cu}, \mathrm{Zn})$-metallothionein in carp hepatopancreas. Comp. Biochem. Phys. C 73, 121-127.

Klein, D., Sato, S., Summer, K.H., 1994. Quantification of oxidized metallothionein in biological-material by a Cd saturation method. Anal. Biochem. 221, 405-409.
Knapen, D., Bervoets, L., Verheyen, E., Blust, R., 2004. Resistance to water pollution in natural gudgeon (Gobio gobio) populations may be due to genetic adaptation. Aquat. Toxicol. 67, 155-165.

Kraak, M.H.S., Scholten, M.C.T. Peeters, W.H.M., Dekock, W.C. 1991. Biomonitoring of heavy-metals in the Western-European rivers Rhine and Meuse using the fresh-water mussel Dreissena polymorpha. Environ. Pollut. 74, 101-114.

Langston, W.J., Zhou, M.J., 1986. Evaluation of the significance of metal-binding proteins in the gastropod Littorina littorea. Mar. Biol. 92, 505-515.

Luoma, S.N., Rainbow, P.S., 2008. Metal Contamination in Aquatic Environments. Science and Lateral Management. Cambridge University Press, Cambridge.

Marigómez, I., Soto, M., Cajaraville, M.P., Angulo, E., Giamberini, L., 2002. Cellular and subcellular distribution of metals in molluscs. Microsc. Res. Tech. 56, 358-392.

McCarty, L.S., Mackay, D., 1993. Enhancing ecotoxicological modeling and assessment. Environ. Sci. Technol. 27, 1719-1728.

Nieboer, E., Richardson, D.H.S., 1980. The replacement of the non-descript term 'Heavy Metals' by a biologically and chemically significant of metal ions. Environ. Pollut. B 1, 3-26.

Ng, T.Y.T., Rainbow, P.S., Amiard-Triquet, C., Amiard, W.C., Wang, W.X., 2007. Metallothionein turnover, cytosolic distribution and the uptake of $\mathrm{Cd}$ by the green mussel Perna viridis. Aquat. Toxicol. 84, 153-161.

Postma, J.F., Mol, S., Larsen, H., Admiraal, W., 1995. Life cycle changes and zinc shortage in cadmium tolerant midges, Chironomus riparius (Diptera) reared in the absence of cadmium. Environ. Toxicol. Chem. 14, 117-122.

Rainbow, P.S., 2002. Trace metal concentrations in aquatic invertebrates: why and so what? Environ. Pollut. 120, 497-507.

Roditi, H.A., Fisher, N.S., Sanudo-Wilhelmy, S.A., 2000. Uptake of dissolved organic carbon and trace elements by zebra mussels. Nature 407, 78-80.

Schneider, D.W., 1992. A bioenergetics model of zebra mussel, Dreissena polymorpha, growth in the Great Lakes. Can. J. Fish. Aquat. Sci. 49, 1406-1416.

Smolders, R., Bervoets, L., De Coen, W., Blust, R., 2004. Cellular energy allocation in zebra mussels exposed along a pollution gradient: linking cellular effects to higher levels of biological organization. Environ. Pollut. 129, 99-112.

Sokal, R.R., Rohlf, F.J., 1998. Biometry, third ed. W.H. Freeman \& Company, New York

Steen Redeker, E., Van Campenhout, K., Bervoets, L., Reynders, H., Blust, R., 2007. Subcellular distribution of $\mathrm{Cd}$ in the aquatic oligochaete Tubifex tubifex, implications for throphic availability and toxicity. Environ. Pollut. 148, 166-175.

Van Campenhout, K., Infante, G.H., Goemans, G., Belpaire, C., Adams, F., Blust, R., Bervoets, L., 2008. A field survey of metal binding to metallothionein and other cytosolic ligands in liver of eels using an on-line isotope dilution method in combination with size exclusion (SE) high pressure liquid chromatography (HPLC) coupled to inductively coupled plasma time-of-flight Mass Spectrometry (ICPTOFMS). Sci. Total Environ. 394, 379-389.

Vijver, M.G., Van Gestel, C.A.M., Lanno, R.P., Van Straalen, N.M., Peijnenburg, W.J.G.M., 2004. Internal metal sequestration and its ecotoxicological relevance: a review. Environ. Sci. Technol. 38, 4705-4712.

Voets, J., Talloen, W., De Tender, T., Van Dongen, S., Covaci, A., Blust, R., Bervoets, L., 2006. Microcontaminant accumulation, physiological condition and bilatera asymmetry in zebra mussels (Dreissena polymorpha) from clean and contaminated surface waters. Aquat. Toxicol. 79, 213-225.

Wallace, W.G., Lee, B.G., Luoma, S.N., 2003. Subcellular compartmentalization of Cd and $\mathrm{Zn}$ in two bivalves. I. Significance of metal-sensitive fractions (MSF) and biologically detoxified metal (BDM). Mar. Ecol. Prog. Ser. 249, 183-197.

Wang, W.X., Rainbow, P.S., 2006. Subcellular partitioning and the prediction of cadmium toxicity to aquatic organisms. Environ. Chem. 3, 395-399.

Wang, D.C., Couillard, Y., Campbell, P.G.C., Jolicoeur, P., 1999. Changes in subcellular metal partitioning in the gills of freshwater bivalves (Pyganodon grandis) living along an environmental cadmium gradient. Can. J. Fish. Aquat. Sci. 56, 774-784

Wang, M.J., Wang, W.X., 2008. Cadmium toxicity in a marine diatom as predicted by the cellular metal sensitive fraction. Environ. Sci. Technol. 42, 940-946. 